\title{
Pengaruh Ukuran Bank, Efisiensi, Dana Pihak Ketiga, Tipe Kepemilikan, dan Likuiditas terhadap Penyaluran Kredit pada Bank Umum Konvensional di Indonesia
}

\author{
Keti Purnamasari \\ keti.purnamasari@polsri.ac.id \\ Politeknik Negeri Sriwijaya
}

\begin{abstract}
Abstrak
Kegiatan menghimpun dan menyalurkan dana masyarakat merupakan kegiatan utama Bank. Bank menghimpun dana dari masyarakat dalam bentuk simpanan giro, simpanan tabungan, dan simpanan deposito. Dana tersebut disalurkan ke masyarakat dalam bentuk kredit seperti kredit investasi, kredit modal kerja, kredit perdagangan, kredit konsumtif, dan kredit produktif. Penyaluran kredit ini dapat dipengaruhi oleh berbagai faktor internal dan eksternal. Penelitian ini menganalisis beberapa faktor internal yang mempengaruhi penyaluran kredit yaitu variabel ukuran bank, efisiensi (BOPO), dana pihak ketiga, tipe kepemilikan, dan likuiditas (Loan to Deposit Ratio) pada 39 Bank Umum Konvensional yang terdaftar di Bursa Efek Indonesia selama 2015 s.d. 2019. Penelitian ini mendapatkan hasil bahwa hanya variabel BOPO yang tidak berpengaruh terhadap penyaluran kredit. Variabel tipe kepemilikan memiliki pengaruh negatif dan signifikan terhadap penyaluran kredit sedangkan variabel ukuran bank, dana pihak ketiga, dan likuiditas memiliki pengaruh positif dan signifikan terhadap penyaluran kredit. Variabel DPK memiliki pengaruh yang paling dominan terhadap penyaluran kredit yang mengindikasikan bahwa masyarakat memiliki kepercayaan terhadap kredibilitas dan eksistensi perbankan sebagai penghimpun dana masyarakat.
\end{abstract}

Kata kunci : penyaluran kredit, ukuran bank, efisiensi, dana pihak ketiga, tipe kepemilikan, likuiditas

\section{Pendahuluan}

Menurut Undang-Undang No. 7 Tahun 1992 tentang perbankan, kredit adalah penyediaan uang atau tagihan yang dapat dipersamakan dengan itu, berdasarkan persetujuan atau kesepakatan pinjam-meminjam antara bank dengan pihak lain yang mewajibkan pihak peminjam untuk melunasi hutangnya setelah jangka waktu tertentu dengan jumlah bunga, imbalan atau pembagian hasil keuntungan.

Bank memberikan kredit dalam rangka mendapatkan keuntungan dari bunga yang diterimanya.Manfaat pemberian kredit ini juga dirasakan oleh masyarakat selaku debitur dalam mengembangkan usahanya.Secara lebih luas, adanya penyaluran kredit ini turut membantu pemerintah dalam peningkatan pembangunan di berbagai sektor.

Kegiatan penghimpunan dan penyaluran dana merupakan kegiatan dasar bank. Dana yang dikumpulkan dari masyakat selanjutnya akan disalurkan kepada masyarakat pula. Penghimpunan dana dari masyarakat (funding) dilakukan dalam bentuk simpanan giro (demand deposit), simpanan tabungan (saving deposit), dan simpanan deposito (time deposit). Penyaluran dana pada masyarakat (lending) dilakukan dalam bentuk kredit seperti kredit investasi, kredit modal kerja, kredit perdagangan, kredit konsumtif, dan kredit produktif (Kasmir, 2015).

Dalam rangka pengumpulan dana, bank senantiasa selalu menjaga kredibilitas dan eksistensinya untuk menjaga kepercayaan masyarakat. Masyarakat harus mempercayai bahwa dana yang disimpan aman. Sebagai pihak yang meminjamkan dana, bank juga harus mempercayai nasabahnya selaku peminjam dana dalam membayar kembali pinjaman yang 
telah diterimanya. Dengan demikian tujuan bank dan nasabah dapat secara bersama-sama tercapai.

Banyak penelitian yang meneliti faktor-faktor yang mempengaruhi penyaluran kredit di Indonesia baik faktor internal maupun eksternal. Faktor internal yang dapat mempengaruhi penyaluran kredit meliputi variabel kecukupan modal, kredit bermasalah, dana pihak ketiga, efisiensi, likuiditas, Net Interest Margin, ukuran bank, dan profitabilitas. Faktor eksternal yang meliputi variabel makro ekonomi yaitu inflasi dan suku bunga Bank Indonesia. Penelitian ini meneliti beberapa faktor internal yang mempengaruhi penyaluran kredit yaitu variabel ukuran bank, rasio efisiensi (BOPO), dana pihak ketiga, tipe kepemilikan (BUMN dan non BUMN), dan rasio likuiditas (Loan to Deposit Ratio/LDR).

Perkembangan penyaluran kredit pada Bank Umum Konvensional di Indonesia dapat dilihat pada gambar di bawah ini.

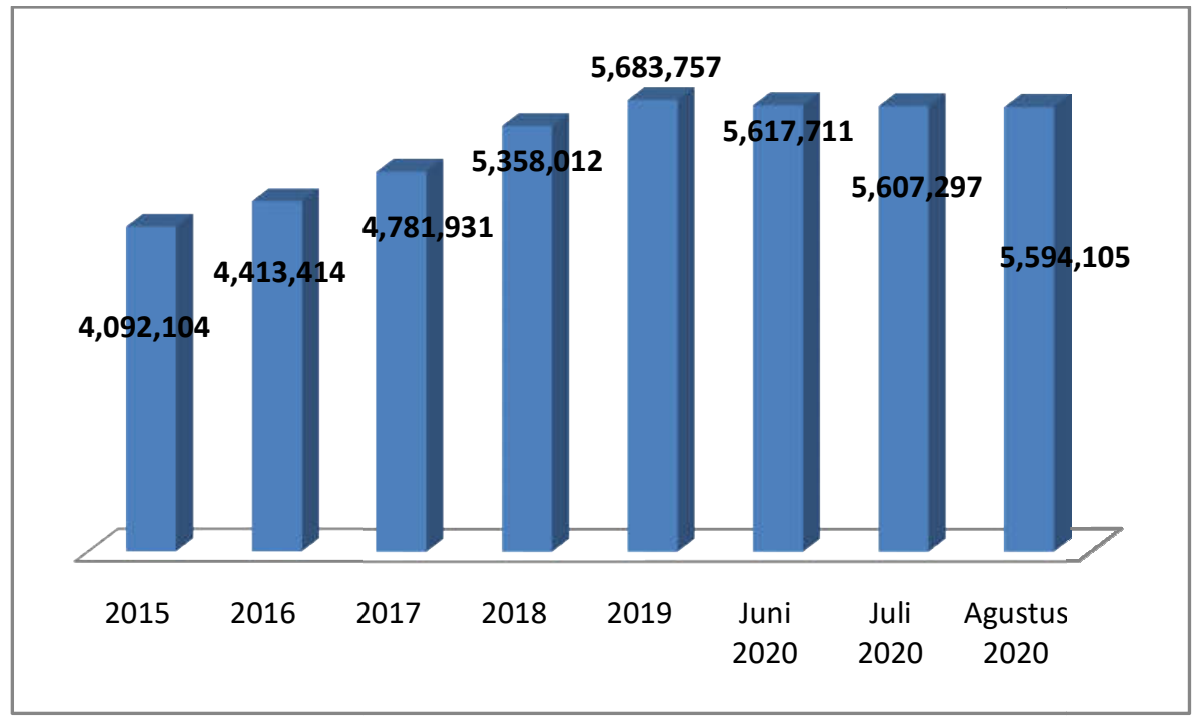

\section{Gambar 1. Perkembangan Penyaluran Kredit pada Bank Umum di Indonesia (dalam miliar rupiah) \\ Sumber : Statistik Perbankan OJK}

Penyaluran kredit di Indonesia meningkat dari tahun 2015 s.d. tahun 2019 dan mengalami penurunan s.d Agustus 2020. Penurunan ini dapat diakibatkan oleh adanya pandemi Corona Virus Disease-19 (COVID-19) yang berdampak pada sektor ekonomi termasuk industri perbankan.

Variabel pertama yang digunakan dalam menganalisis faktor-faktor yang mempengaruhi penyaluran kredit adalah variabel ukuran bank yang diukur dengan logaritma natural dari jumlah aset masing-masing bank. Total aset yang dimiliki bank dapat menggambarkan besarnya skala bank tersebut dan mengindikasikan ketersediaan dana yang banyak pula. Ketersediaan dana yang memadai dapat menggambarkan penyaluran kredit yang besar pula. Perkembangan jumlah aset yang dimiliki oleh Bank Umum di Indonesia dapat dilihat pada gambar di bawah ini.

Sejalan dengan perkembangan penyaluran kreditnya, perkembangan jumlah aset pada Bank Umum di Indonesia juga mengalami peningkatan secara terus-menerus. 


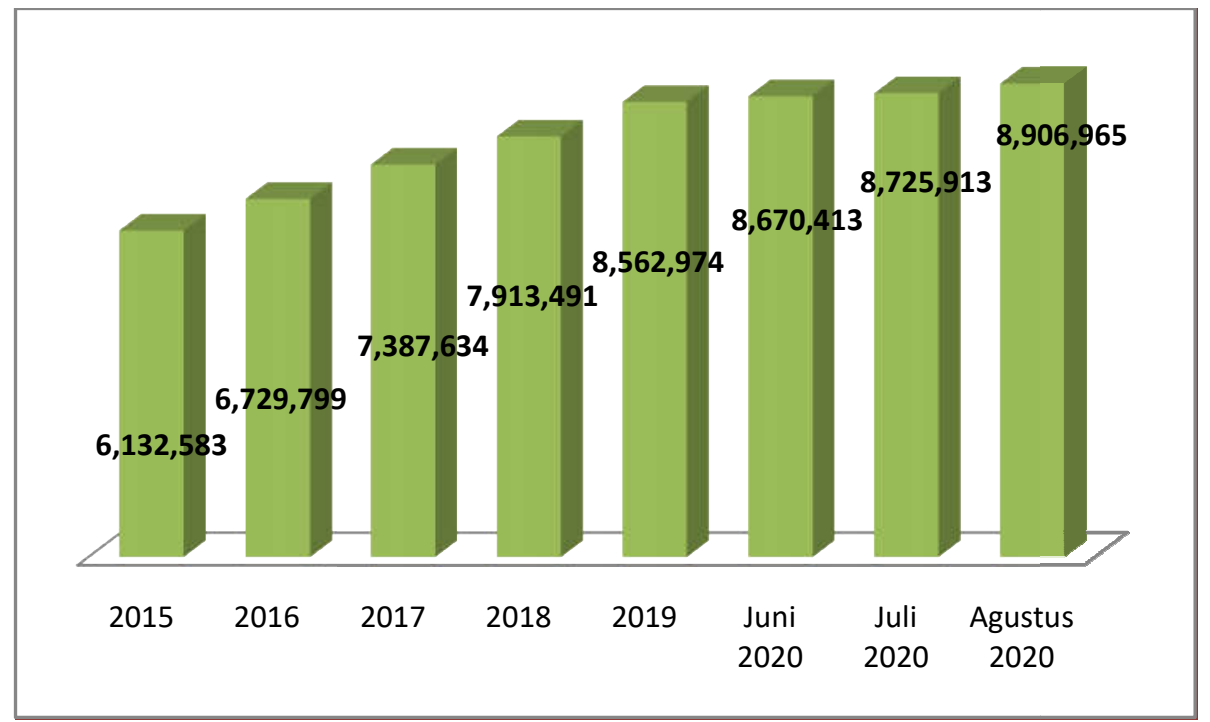

Sumber : Statistik Perbankan OJK (dalam miliar rupiah)

Variabel independen kedua dalam penelitian ini adalah rasio efisiensi yang diukur dengan rasio Beban Operasional terhadap Pendapatan Operasional (BOPO).Rasio ini membandingkan biaya operasional terhadap pendapatan operasional yang mampu diperoleh.Peningkatan pada rasio BOPO mengambarkan ketidakefisienan suatu bank yang berarti semakin besar biaya yang dikeluarkan untuk menghasilkan pendapatannya.Sebaliknya, penurunan pada rasio ini menunjukkan efisiensi yang semakin baik pula, biaya yang dikeluarkan telah sesuai dengan pendapatan yang dihasilkan.Semakin efisien dalam menjalankan operasionalnya, maka penyaluran kredit juga dianggap efisien.

Menurut Surat Edaran Bank Indonesia SE BI No.6/23/DPNP tanggal 31 Mei 2004 besaran Biaya Operasional Pendapatan Operasional yang dikatakan sehat yaitu $\leq 94 \%$. Berdasarkan grafik di atas rasio BOPO pada tahun 2015 s.d. Agustus 2020 berada di bawah $94 \%$ yang menandakan bahwa bank memiliki rasio BOPO yang sehat.

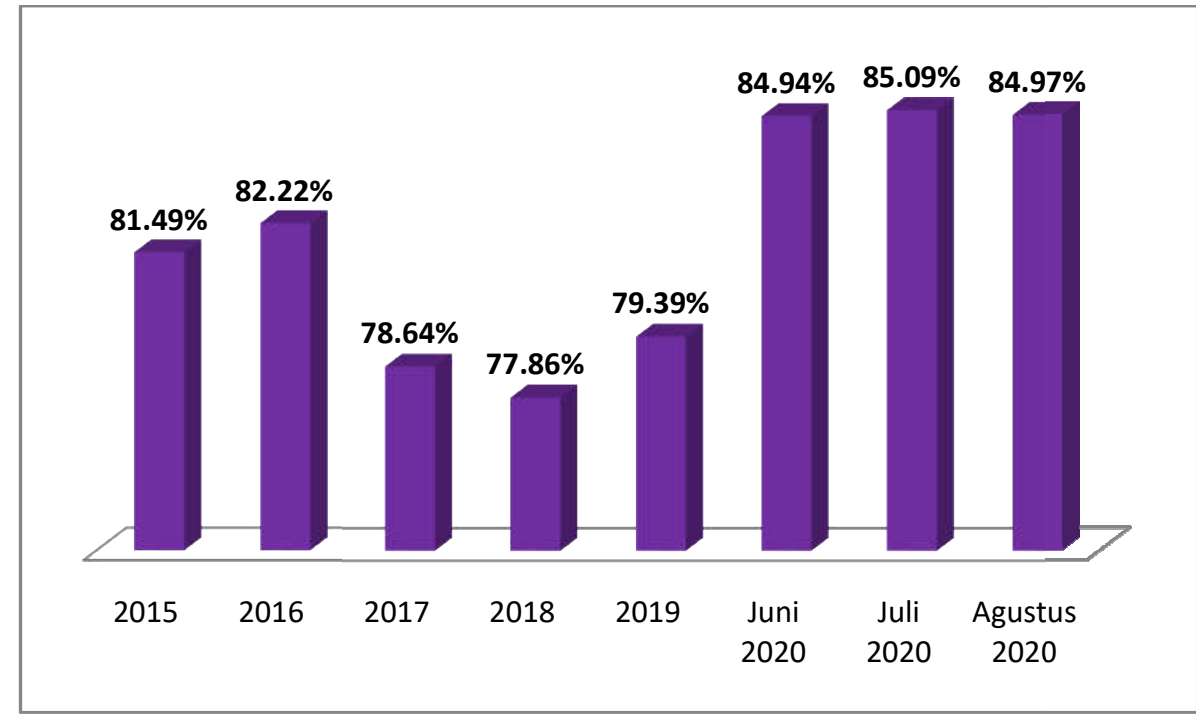

Gambar 3. Persentase Perkembangan Rasio BOPO pada Bank Umum Konvensional Sumber : Statistik Perbankan OJK di Indonesia 
Variabel independen ketiga yang akan dianalisis dalam penelitian ini adalah dana pihak ketiga. Dana pihak ketiga ini merupakan simpanan masyarakat dalam bentuk giro, tabungan, dan doposito. Perkembangan dana pihak ketiga di Indonesia mengalami kenaikan yang signifikan dari tahun 2015 sampai dengan Agustus 2020. Perkembangan dana pihak ketiga tertinggi pada Agustus 2020.

Perkembangan yang signifikan ini menandakan bahwa masyarakat memiliki kepercayaan terhadap kredibitas bank sebagai pihak penghimpun dana. Masyarakat percaya bahwa bank merupakan tempat yang aman dalam menyimpan dana. Pertumbuhan yang tinggi pada dana pihak ketiga juga mengindikasikan pertumbuhan yang meningkat pada penyaluran kreditnya.

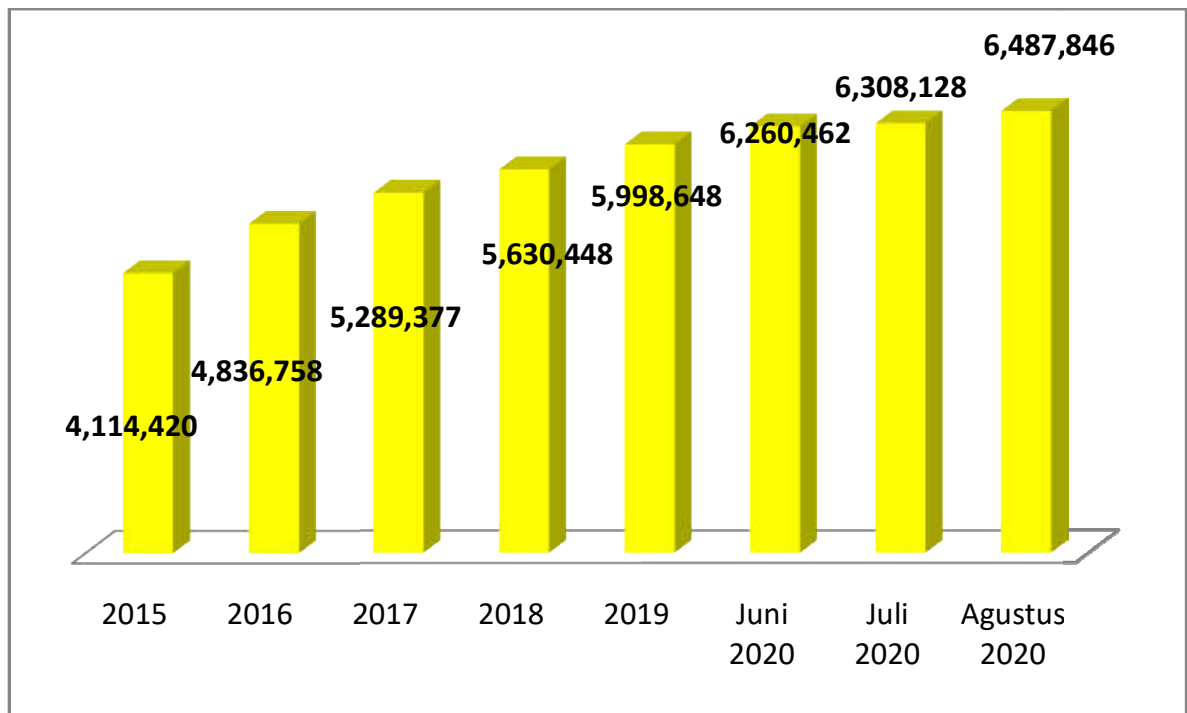

\section{Gambar 4.Perkembangan Dana Pihak Ketiga pada Bank Umum di Indonesia (dalam miliar rupiah) \\ Sumber : Statistik Perbankan OJK}

Penelitian ini juga menganalisis pengaruh variabel tipe kepemilikan (BUMN dan Non BUMN) terhadap penyaluran kredit. Dari 39 bank yang menjadi sampel pada penelitian ini terdapat 9 bank atau sebanyak 23,08\% yang merupakan Badan Usaha Milik Negara (BUMN). Bank BUMN memiliki tugas, insentif, serta kapabilitas yang cukup untuk dapat terus melakukan ekspansi kredit sedangkan bank swasta lebih berhati-hati terutama dalam menyalurkan permintaan kredit yang tergolong berisiko.

Variabel likuiditas dalam penelitian ini diukur dengan menggunakan nilai Loan to Deposit Ratio (LDR). LDR merupakan rasio untuk mengukur jumlah kredit dengan jumlah dana pihak ketiga yang dihimpun oleh bank. Rasio LDR yang tinggi menggambarkan keadaan bank yang tidak likuid dimana bank dapat mengalami kesulitan dalam memenuhi kewajiban jangka pendeknya. Rasio LDR yang rendah menggambarkan semakin likuid suatu bank sehingga bank mampu membayar kewajiban jangka pendeknya namun hal ini juga dapat mengindikasikan terdapat dana menganggur (idle fund) yang tidak dimanfaatkan oleh bank dalam memperoleh pendapatan yang lebih besar (Agustina \& Wijaya, 2013).

Nilai Loan to Deposit Ratio yang ditetapkan oleh Bank Indonesia sesuai dengan peraturan No. 15/7/PBI/2013 yakni 78\% - 92\%. Berdasarkan perkembangan LDR seperti yang terlihat pada gambar di bawah ini, nilai LDR mengalami penurunan pada tingkat LDR yang lebih baik sampai dengan Agustus 2020.Nilai LDR yang tinggi menggambarkan jumlah penyaluran kredit yang tinggi pula. 


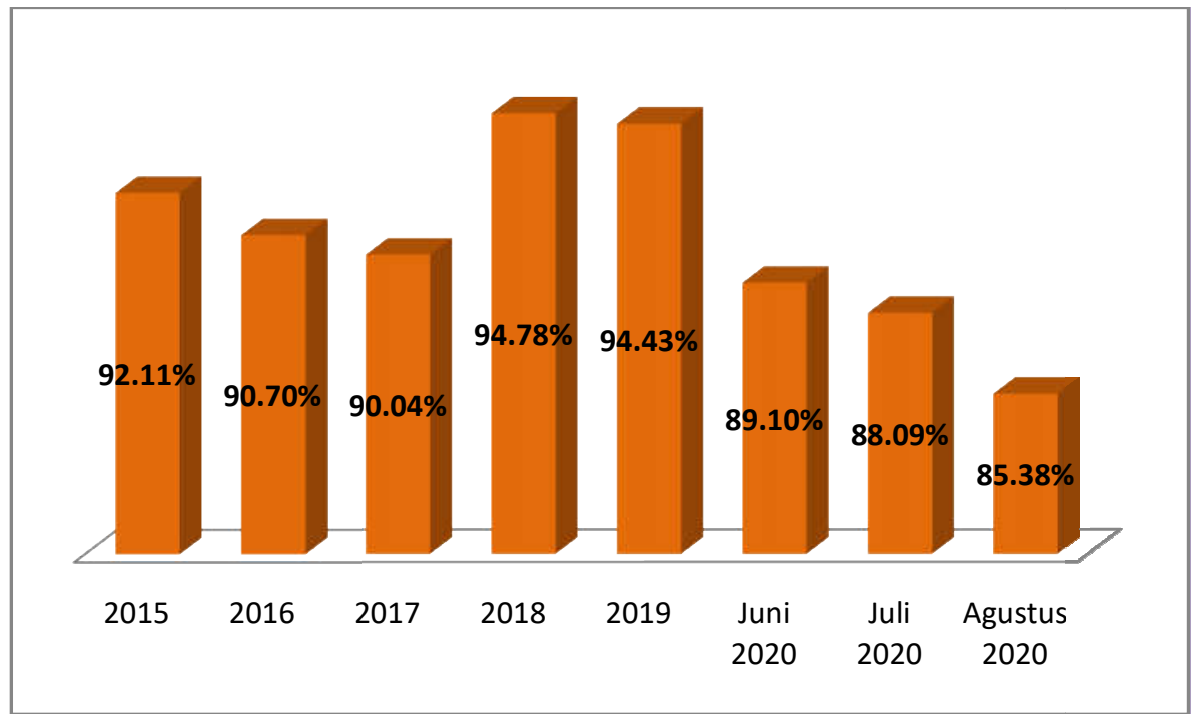

Gambar 5. Persentase Perkembangan Rasio Loan to Deposit Ratio (LDR) pada Bank Umum Konvensional di Indonesia

Sumber : Statistik Perbankan OJK

\section{Kerangka Konseptual}

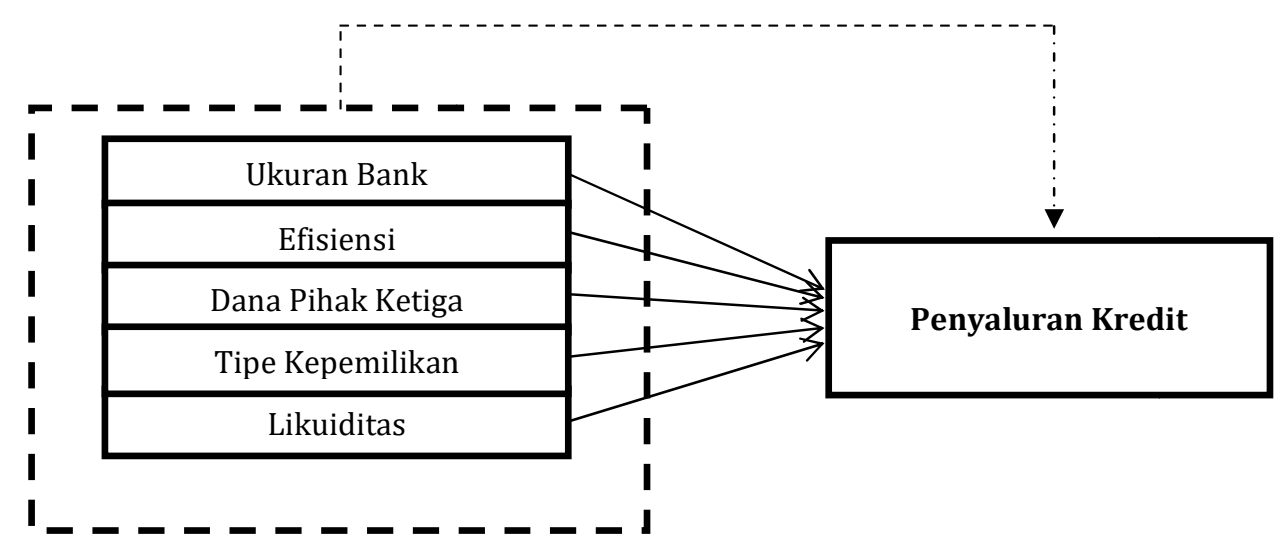

Keterangan :

\section{Gambar 6. Kerangka Koseptual}

: berpengaruh secara simultan

: berpengaruh secara parsial

\section{Metodologi}

\subsection{Penentuan Sampel}

Populasi penelitian ini adalah perusahaan yang terdaftar pada sektor keuangan dengan sub sektor Bank di Bursa Efek Indonesia (BEI). Pemilihan sampel dalam penelitian ini menggunakan metode purposive sampling dan dipilih berdasarkan kriteria tertentu. Adapun kriteria sampel dari penelitian ini sebagai berikut : Bank Umum Konvensional yang terdaftar pada Bursa Efek Indonesia (BEI) selama periode 2015 s.d. 2019 dan memiliki laporan keuangan dan laporan tahunan lengkap selama periode penelitian. Berdasarkan kriteria di atas terdapat 39 Bank Umum Konvensional yang menjadi sampel pada penelitian ini selama lima tahun. 


\subsection{Variabel Penelitian}

Variabel independen dalam penelitian ini terdiri dari variabel ukuran bank, efisiensi, dana pihak ketiga, tipe kepemilikan, dan likuiditas sedangkan variabel dependen dalam penelitian ini adalah penyaluran kredit. Secara lebih ringkas variabel-variabel penelitian ini dijelaskan pada tabel di bawah ini :

\section{Tabel 1.Variabel Penelitian}

\begin{tabular}{|l|l|}
\hline \multicolumn{1}{|c|}{ Variabel } & \multicolumn{1}{c|}{ Pengukuran } \\
\hline Penyaluran Kredit & Jumlah Penyaluran kredit = Ln (jumlah kredit yang disalurkan) \\
\hline Ukuran Bank & Size $=$ Ln Total Asset \\
\hline Efisiensi & BOPO $=\frac{\text { Beban Operasional }}{\text { Pendapatan Operasional }} \times 100 \%$ \\
\hline Dana Pihak Ketiga & Dana pihak ketiga = Ln (tabungan + giro + deposito) \\
\hline Tipe Kepemilikan & $\begin{array}{l}\text { Variabel dummy tipe kepemilikan : } \\
1 \text { untuk Bank BUMN dan 0 untuk Bank Non BUMN }\end{array}$ \\
\hline Likuiditas & Loan to Deposit Ratio $($ LDR $)=\frac{\text { Total Loan }}{\text { Total Deposite }+ \text { Equity }} \times 100 \%$ \\
\hline
\end{tabular}

\section{3. $\quad$ Metode Analisis}

Pengujian hipotesis dalam penelitian ini menggunakan metode analisis regresi berganda. Persamaan matematis dalam penelitian ini adalah:

\section{$\operatorname{LnPK}=\beta_{0}+\beta_{1}$ Size $+\beta_{2}$ BOPO $+\beta_{3} \operatorname{LnDPK}+\beta_{4}$ Own $+\beta_{5} L D R+\varepsilon$}

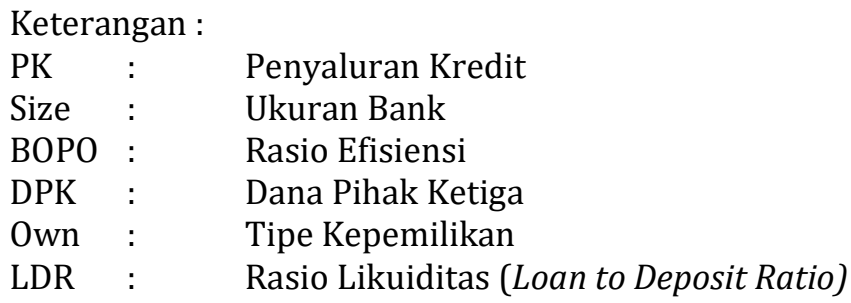

Secara statistik, untuk mengukur ketepatan fungsi regresi dalam menaksir nilai aktual dapat diukur dari nilai koefisien determinasi, nilai statistik $\mathrm{F}$, dan nilai statistik t. Koefisien determinasi $\left(\mathrm{R}^{2}\right)$ mengukur kemampuan variabel independen dalam menerangkan variasi variabel dependen. Uji statistik $\mathrm{F}$ pada dasarnya menunjukkan apakah semua variabel independen dalam model mempunyai pengaruh terhadap variabel dependen secara simultan. Uji statistik t pada dasarnya menunjukkan seberapa jauh pengaruh variabel independen dalam menerangkan variasi variabel dependen secara individual (Ghozali, 2013).

\section{Analisis Data dan Pembahasan}

\subsection{Analisis Data}

Output SPSS di bawah ini menunjukkan nilai R Square sebesar 0,935 yang berarti sebanyak 93,50\% variabel independen mampu menjelaskan variabel dependen sedangkan sisanya sebesar $6,5 \%$ dijelaskan oleh faktor-faktor lain di luar penelitian ini. Nilai yang mendekati $100 \%$ berarti variabel-variabel independen dalam penelitian ini memberikan hampir semua informasi yang dibutuhkan untuk memprediksi variabel dependen.

Tabel 2. Nilai Koefisien Determinasi

\begin{tabular}{|c|c|c|c|}
\hline Model & R & R Square & Adjusted R Square \\
\hline 1 & 0.967 & 0.935 & 0.933 \\
\hline
\end{tabular}

Sumber : data diolah 
Tabel di bawah ini memperlihatkan hasil uji statistik $\mathrm{F}$ dengan tingkat signifikansi sebesar < 0,05 yaitu 0,000 yang berarti semua varibael independen dalam model ini memiliki pengaruh terhadap variabel dependen secara simultan.

Tabel 3. Hasil Uji Statistik F

\begin{tabular}{|l|l|c|c|c|c|c|}
\hline \multicolumn{2}{|c|}{ Model } & $\begin{array}{c}\text { Sum of } \\
\text { Squares }\end{array}$ & df & $\begin{array}{c}\text { Mean } \\
\text { Square }\end{array}$ & F & Sig. \\
\hline \multirow{2}{*}{1} & Regression & 586.472 & 5 & 117.294 & 541.262 & 0.000 \\
\cline { 2 - 7 } & Residual & 40.957 & 189 & 0.217 & & \\
\cline { 2 - 7 } & Total & 627.429 & 194 & & & \\
\hline
\end{tabular}

Sumber : data diolah

Hasil uji statistik t pada tabel di bawah ini memperlihatkan hasil bahwa hanya variabel BOPO yang memiliki tingkat signifikansi > 0,05 yang berarti bahwa hanya variabel BOPO yang tidak berpengaruh terhadap penyaluran kredit. Variabel tipe kepemilikan memiliki pengaruh negatif dan signifikan terhadap penyaluran kredit sedangkan variabel ukuran bank, dana pihak ketiga dan likuiditas memiliki pengaruh positif dan signifikan terhadap penyaluran kredit. Hasil di bawah ini juga memperlihatkan bahwa variabel DPK memiliki pengaruh yang paling dominan terhadap penyaluran kredit.

Tabel 4. Hasil Uji Statistik t

\begin{tabular}{|l|l|c|c|c|}
\hline \multicolumn{2}{|c|}{ Model } & B & t & Sig \\
\hline \multirow{4}{*}{1} & (Constant) & -0.398 & -0.481 & 0.631 \\
\cline { 2 - 5 } & SIZE & 0.124 & 3.566 & 0.000 \\
\cline { 2 - 5 } & BOPO & -0.001 & -0.634 & 0.527 \\
\cline { 2 - 5 } & DPK & 0.862 & 27.651 & 0.000 \\
\cline { 2 - 5 } & OWN & -0.225 & -2.345 & 0.020 \\
\cline { 2 - 5 } & LDR & 0.008 & 3.769 & 0.000 \\
\hline
\end{tabular}

Sumber : data diolah

\subsection{Pembahsan}

\subsubsection{Pengaruh Ukuran Bank Terhadap Penyaluran Kredit}

Pada penelitian ini, ukuran bank menggambarkan besar atau kecilnya suatu bank jika dilihat dari total asetnya.Hasil penelitian ini mennujukkan hasil bahwa ukuran bank berpengaruh positif terhadap penyaluran kreditnya. Bank yang memiliki total aset yang besar dianggap mampu menyalurkan kredit yang besar pula. Hasil penelitian ini sejalan dengan Adnan et al. (2016).

\subsubsection{Pengaruh Efisiensi Terhadap Penyaluran Kredit}

Penelitian ini mendapatkan hasil bahwa rasio BOPO tidak berpengaruh terhadap penyaluran kredit dengan tingkat signifikansi $>0,05$. Penelitian ini memiliki hasil yang sama dengan Putra (2017). Meskipun sampai dengan Agustus 2020, rasio BOPO mengalami peningkatan, pihak bank tetap melakukan penyaluran kredit. Biaya operasional yang dikeluarkan oleh bank digunakan untuk membiayai kegiatan operasional lainnya. Perubahan pada rasio ini tidak berpengaruh terhadap keputusan bank dalam menyalurkan kreditnya.

\subsubsection{Pengaruh Dana Pihak Ketiga Terhadap Penyaluran Kredit}

Penelitian ini mendapatkan hasil bahwa DPK berpengaruh positif terhadap penyaluran kredit dengan tingkat signifikansi $<0,05$. Dana pihak ketiga yang dihimpun oleh pihak bank berupa tabungan, giro, dan deposito merupakan sumber dana terbesar yang mampu dihimpun bank dari masyarakat. Apabila dilihat pada gambar 4, perkembangan dana pihak ketiga sampai dengan Agustus 2020 mengalami peningkatan secara terus-menerus. Artinya masyarakat masih mempercayai kredibilitas dan eksistensi bank sebagai pihak yang mampu menyimpan dana mereka secara aman. Semakin banyak dana yang mampu dihimpun bank dari masyarakat maka akan menyebabkan semakin besar pula kredit yang disalurkan. Penelitian ini memiliki hasil yang sama dengan Nusantara et al. (2020), Haini (2013), dan Sari et al. (2012). 


\subsubsection{Pengaruh Tipe Kepemilikan Terhadap Penyaluran Kredit}

Penelitian ini mendapatkan hasil bahwa tipe kepemilikan pemerintah (Bank BUMN) berpengaruh negatif terhadap penyaluran kredit.Sebagai pemegang saham terbesar pada Bank BUMN, pemerintah terkadang memiliki tujuan yang berbeda dengan pihak manajemen bank karena kebijakan pemerintah tidak terlepas dari unsur politik. Menurut (Sabrina \& Muharam, 2015), Bank dengan kepemilikan pemerintah sering diasosiasikan dengan buruknya kinerja seperti rendahnya profitabilitas dan produktifitas, ketidakefisienan dalam operasionalnya, serta menghadapi risiko yang lebih besar. Menurut Suria (2020), kurangnya performa bank BUMN pada tahun 2019 disebabkan lemahnya permintaan kredit dari tiga sektor utama penunjang ekonomi nasional, seperti perdagangan, pertanian dan pengolahan. Permintaan kredit lebih banyak berasal dari sektor infrastruktur dan Kredit Usaha Rakyat (KUR).

\subsubsection{Pengaruh Likuiditas Terhadap Penyaluran Kredit}

Hasil penelitian ini menunjukkan bahwa rasio LDR memiliki pengaruh yang positif terhadap penyaluran kredit dengan tingkat signifikansi $<0,05$. Hasil ini sejalan dengan penelitian Roring (2013) dan Amelia \& Murtiasih (2017). LDR menunjukkan kemampuan bank dalam menyalurkan dana kepada debitur yang bersumber dari dana masyarakat yang berhasil dihimpun. Semakin tinggi LDR menggambarkan semakin besar jumlah kredit yang disalurkan kepada masyarakat.Sebaliknya, semakin rendah LDR maka semakin kecil jumlah kredit yang disalurkan. Bank harus menyalurkan kredit kepada masyarakat dengan memperhatikan jumlah dana yang berhasil dihimpun.

\section{Kesimpulan dan Rekomendasi}

Penelitian ini mendapatkan hasil bahwa variabel ukuran bank, dana pihak ketiga, dan likuiditas berpengaruh positif terhadap penyaluran kredit sedangkan tipe kepemilikan berpengaruh negatif terhadap penyaluran kredit. Variabel efisiensi tidak berpengaruh terhadap penyaluran kredit. Variabel DPK memiliki pengaruh yang paling dominan di antara variabelvariabel yang berpengaruh terhadap penyaluran kredit, yang mengindikasikan bahwa masyarakat memiliki kepercayaan terhadap kredibilitas dan eksistensi perbankan sebagai penghimpun dana masyarakat.

Berdasarkan hasil ini, penulis menyarankan agar pihak bank tetap menjaga kepercayaan masyarakat melalui peningkatan kredibilitas dan eksistensinya sebagai penghimpun dana mastarakat. Keberhasilan kinerja perbankan juga tidak luput dari peran Otoritas Jasa Keuangan (OJK) dalam menjaga stabilitas perbankan.OJK juga harus memastikan perbankan menerapkan prinsip kehati-hatian, penerapan manajemen risiko, dan azas perbankan yang sehat dalam kegiatan operasionalnya sehingga kepercayaan masyarakat terhadap perbankan pun meningkat.

\section{Daftar Pustaka}

Adnan, A., Ridwan, R., \& Fildzah, F. (2016). Pengaruh Ukuran Bank, Dana Pihak Ketiga, Capital Adequacy Ratio, dan Loan to Deposit Ratio terhadap Penyaluran Kredit Pada Perusahaan Perbankan yang Terdaftar di Bursa Efek Indonesia Tahun 2011-2015. Jurnal Dinamika Akuntansi Dan Bisnis, 3(2), 49-64.

Agustina, \& Wijaya, A. (2013). Analisis Faktor-Faktor yang Mempengaruhi Loan Deposit Ratio Bank Swasta Nasional di Bank Indonesia. Jurnal Wira Ekonomi Mikroskil, 3(2), 101-109.

Amelia, K., \& Murtiasih, S. (2017). Analisis Pengaruh DPK, LDR, NPL dan CAR terhadap Jumlah Penyaluran Kredit Pada PT. Bank QNB Indonesia, Tbk Periode 2005 - 2014. Jurnal Ilmiah Ekonomi Bisnis, 22(1), 97059.

Ghozali, I. (2013). Aplikasi Analisis Multivariate Dengan Program IBM SPSS 21. In International Journal of Management Studies. Badan Penerbit Universitas Diponegoro. 
Haini, F. N., Tyasari, I., \& Mustikowati, R. I. (2015).Analisis Pengaruh Dana Pihak Ketiga (DPK), Non Performing Loans (NPL), dan Ukuran Perusahaan Terhadap Penyaluran Kredit Perusahaan Perbankan yang Terdaftar di Bursa Efek Indonesia. Jurnal Riset Mahasiswa Manajemen, 3(1).

Kasmir. 2015. Manajemen Perbankan. PT RajaGrafindo Persada. Jakarta, Indonesia.

Sinurat, F. S., Nainggolan, P., \& Panjaitan, P. D. (2020).Faktor-faktor yang Mempengaruhi Penyaluran Kredit pada Bpr Nusantara Bona Pasogit 34 Pematangsiantar.Jurnal Ekuilnomi, 2(2), 73-85.

Otoritas Jasa Keuangan. 2020. Statistik Perbankan Indonesia Agustus 2020.0toritas Jasa Keuangan, Republik Indonesia : Jakarta.

Putra, M. D. M. (2017). Pengaruh Capital Adequacy Ratio, Return on Asset, Operations Expenses/Operations Incomes, dan Non Performing Loan terhadap Penyaluran Kredit Bank Campuran Tahun 2009-2013. Jurnal Manajemen Dan Bisnis (ALMANA), 1(1), 1-10.

Rasdianto, Fajar Yusuf. Bongkar Kinerja 4 bank BUMN 2019 yang Terseok-Seok.31 Januari 2020, https://www.alinea.id/bisnis/bongkar-kinerja-4-bank-bumn-2019-yang-terseok-seokb1ZGG9riu.diakses pada 27 November 2020.

Richard, M. Bank BUMN Jadi Tumpuan Penyaluran Kredit Baru.5 Agustus 2020, https://finansial.bisnis.com/read/20200805/90/1275508/bank-bumn-jadi-tumpuanpenyaluran-kredit-baru.diakses pada 27 November 2020.

Roring, G. D. J. (2013). Analisis Determinan Penyaluran Kredit oleh Bank Perkreditan Rakyat (BPR) di Kota Manado. Jurnal EMBA, 1(3), 1030-1040.

Sabrina, F. N., \& Muharam, H. (2015). Analisis Pengaruh Kepemilikan Pemerintah, Kepemilikan Asing, Risiko Likuiditas Dan Risiko Kredit Terhadap Kinerja Keuangan Bank. Diponegoro Journal of Management, 4(1), 1-13.

Sari, G. N. (2013) Faktor-Faktor Yang Mempengaruhi Penyaluran Kredit Bank Umum Di Indonesia (Periode2008.1 - 2012.2).Jurnal EMBA, 1(3), 931-941.

UU No. 7 tahun 1992 tentang Perbankan 
